\title{
The Right of a Criminal Defense Attorney to Withhold Physical Evidence Received from His Client
}

\section{INTRODUCTION}

Several trials of the past year have raised serious questions concerning the conduct of attorneys. While courtroom behavior has received the most publicity, ${ }^{1}$ questions concerning the out-of-court actions of an attorney on behalf of his client have also been raised. Early this year, a Chicago attorney representing members of the Black Panther Party was found in contempt of court for failure to respond to a subpoena duces tecum to produce certain physical evidence directly related to an incident in which his clients were involved. 2 This comment will consider the general duty of an attorney who receives from a client, directly or indirectly, physical evidence related to the commission of a crime. ${ }^{3}$ Two alternatives exist: (1) the attorney may, under all circumstances, retain possession of such evidence; or (2) he may be under a

I Many, if not most, of the issues raised by these trials have been discussed, in some cases ad nauseam, in both the public and academic presses.

2 Two members of the Black Panther Party were killed in a "shootout" with police in December, 1969. A Close Look at "Black Panther" Shootouts, U.S. NEws \& W. RFP., Dec. 22,1969 , at 25 . The evidence, desired by a coroner's jury and a grand jury to determine whether police or Panthers shot first, included a door panel, four mattresses, two box springs, a window shutter, a window and frame, and three boxes of evidence, presumably containing spent cartridges, slugs, shotgun pellets, pieces of wood and plaster, and so on. Subpoena Duces Tecum (copy) in Record, People ex rel. Andrews v. Woods, No. 42863 (Sup. Ct. Ill., Jan. 17, 1970) (typescript, no pagination); O'Brian, Panther Lawyer Gives Up Evidence, Avoids Jail, Chicago Tribune, Jan. 20, 1970, at 7. The attorney was released on a habeas corpus petition to the Illinois Supreme Court on condition that he produce the evidence two days later. $1 d$. The habeas corpus petition alleged denial of the right to counsel at a contempt hearing on the subpoena, and did not speak to the merits of the withholding issue. Since the evidence was produced, the issue became moot. Order of Justice Walter V. Schaefer in Record, People ex rel. Andrews v. Woods, supra. The attorney originally withheld the evidence on the grounds that police would change their testimony if he produced it before police testimony was concluded. O'Brian, Panther Lawyer Refuses to Testify, He's Jailed 30 Days, Chicago Tribune, Jan. 17, 1970, at 7.

3 The evidence in the Panther case was in the hands of police, in that they guarded the apartment and its contents until their investigation was completed. Thus it never was a part of the "confidential" attorney-client relationship and hence is outside the topic as discussed herein. It is elementary in consideration of the attorney-client privilege that if a third party hears a conversation it is not confidential and therefore not privileged. The same reasoning would apply a fortiori to physical evidence. 
duty to produce such evidence voluntarily and hence may be subject to compulsory process if he fails to produce it.4

A criminal defendant cannot be compelled to produce the weapons used for the commission of a crime or the fruits of a crime because he is protected by the privilege against self-incrimination. 5 The reasoning behind this rule usually asserts that if he were compelled to produce the physical evidence he would be "testifying" that the item produced is the item demanded. 'The prosecution may, however, obtain the evidence through the use of a search warrant. ${ }^{7}$ This is not "testimonial" on the defendant's part because the prosecution must prove his connection with the item produced. To compel the defendant's attorney to produce the evidence would, seemingly, be similar to compelling the client to testify. A collateral effect of such forced production might involve effectively denying the right to counsel ${ }^{8}$ by inhibiting the defen-

4 A third alternative exists: the attorney may be entitled to retain the evidence unless ordered to produce it. This alternative does not seem a viable one, however, since it would almost certainly result in routine subpoenas duces tecum for attorneys to produce evidence. Thus, this comment considers the situation in an either/or context. Either he may retain the evidence under all circumstances or he must produce it under all circumstances.

5 See 8 J.H. WigmoRe, Evidence § 2264 (J.T. McNaughton rev. ed. 1961) [hereinafter cited as WIGMORE]: “(1) It follows that the production of documents or chattels by a person (...) in response to a subpoena [or other process] relying on his moral responsibility for truthtelling, may be refused under the protection of the [self-incrimination] privilege. This is universally conceded. For though the documents or chattels thus sought be not oral in form, and though they be already in existence and not desired to be first written and created by a testimonial act or utterance of the person in response to the process, still there is testimonial disclosure implicit in their production. It is the witness' assurance, compelled as an incident of the process, that the articles produced are the ones demanded. . . . Testimonial acts of this sort-authenticating or vouching for preexisting chattels-are not typical of the sort of disclosures which are caught in the main current of history and sentiments giving vitality to the [self-incrimination] privilege. Yet they are within the border of its protection."

6 Id.

78 WIGMORE § 2264: “(2) Furthermore, it follows that documents or chattels obtained from the person's control without the use against him of process relying on his truthtelling are not within the scope of the [self-incrimination] privilege. As Mr. Justice Holmes said, "A party is privileged from producing the evidence but not from its production.' [Johnson v. United States, 228 U.S. 457, 458 (1913)]. . . . Obviously, the proof of their authenticity, or other circumstances affecting them, may and must be made by the testimony of other persons, without any employment of the accused's oath or testimonial responsibility. This distinction is illustrated in a variety of applications to documents and chattels obtained by search and seizure independent of testimonial process ...." This comment does not deal with any evidence of a nature which cannot be seized by search warrant, since the problem herein defined is absent in such a situation. See discussion in Harris v. United States, 331 U.S. 145, 154 (1947) (Vinson, C.J.), overruled as to particular issue of law decided, Chimel v. California, 395 U.S. 768 (1969). See also Warden v. Hayden, 387 U.S. 294 (1967).

8 E.g., Gideon v. Wainwright, 372 U.S. 335 (1963), the landmark "right-to-counsel" case which has spawned many other cases. 
dant from confiding in his attorney. By producing information against his client, the attorney would become an advocate against his own client, ${ }^{9}$ a role the legal profession has long resisted. On the other hand, the legal profession, for just as long a time, has considered its members to be officers of the court, owing a duty to the court as well as to the client. To permit the withholding of physical evidence-which may in many cases preclude the prosecution from getting the evidence at all ${ }^{10}$ - seems to contradict the lawyer's duty to the court.

This comment relies on an implicit premise which should be made explicit: Attorneys should not be subjected to a physical search with respect to every criminal case in which the prosecution has not found a piece of relevant physical evidence. Either the attorney should be permitted to withhold the evidence or he should be obligated to produce it. Such obligation, if imposed, should be enforced by the contempt power after issuance of a subpoena to produce, not by a search warrant. The resolution of the problem posed herein requires a balancing of the interests of the defendant-his constitutional privilege against self-incrimination, his right to counsel, and the evidentiary privilege against divulgence of confidential attorney-client communication-with the interest of society in protecting its members through the apprehension and conviction of those who commit crimes.

There is little case law to aid in resolving this problem. While one would suppose the issue would arise frequently in criminal prosecutions, ${ }^{11}$ it apparently has not-either because the attorney willingly turns over the evidence, ${ }^{12}$ or because he refuses to accept it from his client in the first place. ${ }^{13}$ However, the attorney's refusal to accept evidence is a strong indication to the client that he should destroy it, ${ }^{14}$

9 "The client is presumed innocent, and it seems inconsistent with this premise that the lawyer could be required in a criminal case to present evidence of guilt while at the same time asserting innocence." Comment, An Attorney in Possession of Evidence Incriminating His client, 25 WASH. \& LEE L. REv. 133, 136 (1968).

10 Oral evidence can thus be distinguished from physical evidence, since the prosecution often has other possible ways of getting the facts which a defendant tells his lawyer, while, once the lawyer has the physical evidence, there is no other way for the prosecution to get it.

11 Comment, supra note 9, at 135.

12 The Ethics Committee of the New York County Lawyer's Association was asked if it had an opinion on the issue or any authority on point. The chairman replied, "I would suspect that such action on the part of a lawyer would be so clearly improper that no lawyer would think of seeking a ruling on the matter from an Ethics Committee." Reported in Comment, Fruits of the Attorney-Client Privilege: Incriminating Evidence and Conflicting Duties, 3 DUQUESNE L. REv. 239, 248 (1965).

13 There is a third alternative-that the lawyer keeps the evidence and the prosecution never finds out that he has it, thereby avoiding the question entirely.

14 Comment, supra note 12 , at 249. 
thus raising a different ethical question which is beyond the scope of this comment. This comment will consider: (1) whether it is appropriate to consider the withholding of physical evidence by an attorney as an ethical question under the Canons of Professional Ethics and its replacement, the Code of Professional Responsibility; ${ }^{15}$ (2) whether it is appropriate to consider whether the conduct of the lawyer in withholding physical evidence is itself a criminal act; and (3) whether, as a matter of legal policy, the evidentiary privilege against divulgence of confidential communications between an attorney and his client should permit the attorney to withhold physical evidence, the decision being based on an analysis of the benefits gained from exclusion versus the benefits expected from requiring production. ${ }^{16}$

\section{The Ethical ANalysis}

Some courts insist on discussing the Canons of Professional Ethics in their opinions, ${ }^{17}$ though basing a conclusion thereon undoubtedly involves the logical fallacy of petitio principii or "begging the question."18 Cited in support of the proposition that the ABA Canons would require the attorney to withhold the evidence are the "undivided fidelity" requirement of Canon 6,19 the requirement of Canon 15 that " $[t]$ he lawyer owes 'entire devotion to the interest of the client $\ldots,,^{\prime 20}$ and the duty to preserve a client's confidences of Canon 37.21

15 While the Code has now replaced the Canons as the ABA's ethical standard, some jurisdictions have their own standards based on the Canons which may not as yet have been revised to conform to the Code. Thus, consideration of both seems appropriate.

16 E.g., 97 C.J.S. Witnesses $\$ 276$ (1957): "In order for the privilege to apply, the resultant injury to the relation of attorney and client by the disclosure of the communication must be greater than the benefit thereby gained for the correct disposal of the litigation." Cases cited id. at n.60.

17 E.g., In re Ryder, 263 F. Supp. 360 (E.D. Va.), aff'd, 381 F.2d 713 (4th Cir. 1967) (per curiam). For an ethical approach without mention of the Canons, see Clark v. State, 159 Tex. Crim. 187, 261 S.W.2d 339, cert. denied, 346 U.S. 855, rehearing denied, 346 U.S. 905 (1953). In Ryder the issue was indeed whether the attorney had breached the Virginia Canons of Ethics (same as ABA Canons), but the actual decision rested on a determination that the conduct involved was not within the attorney-client evidentiary privilegeclearly not an ethical question in itself. See further discussion of the case in text at notes 39-52 infra. In Clark, a telephone operator was permitted to testify to a conversation wherein an attorney told his client to get rid of the murder weapon. The court decided such conduct was not within the attorney-client privilege. See text at notes 63-67 infra.

18 I.M. Copt, Introduction to LoGic 65, 66 (2d ed. 1961).

19 aba Canons of Professtonal Ethics No. 6 [hereinafter cited as aba Canons]: "The obligation to represent the client with undivided fidelity and not to divulge his secrets or confidences forbids also the subsequent acceptance of retainers or employment from others in matters adversely affecting any interest of the client with respect to which confidence has been reposed."

20 ABA Canons No. 15 (in full):

How Far a Lawyer May Go in Supporting a Client's Cause.

Nothing operates more certainly to create or to foster popular prejudice against

lawyers as a class, and to deprive the profession of that full measure of public 
On the other hand, the proposition that the attorney should not withhold the evidence is supported by Canon 5, prohibiting the prosecution from withholding evidence of a defendant's innocence, ${ }^{22}$ Canon 22 calling for an attitude of "candor and fairness" to the court, ${ }^{23}$ Canon 29

esteem and confidence which belongs to the proper discharge of its duties than does the false claim, often set up by the unscrupulous in defense of questionable transactions, that it is the duty of the lawyer to do whatever may enable him to succeed in winning his client's cause.

It is improper for a lawyer to assert in argument his personal belief in his client's innocence or in the justice of his cause.

The lawyer owes "entire devotion to the interest of the client, warm zeal in the maintenance and defense of his rights and the exertion of his utmost learning and ability," to the end that nothing be taken or be withheld from him, save by the rules of law, legally applied. No fear of judicial disfavor or public unpopularity should restrain him from the full discharge of his duty. In the judicial forum the client is entitled to the benefit of any and every remedy and defense that is authorized by the law of the land, and he may expect his lawyer to assert every such remedy or defense. But it is steadfastly to be borne in mind that the great trust of the lawyer is to be performed within and not without the bounds of the law. The office of attorney does not permit, much less does it demand of him for any client, violation of law or any manner of fraud or chicane. He must obey his own conscience and not that of his client.

See In re Ryder, 263 F. Supp. 360, 369 (1967): "He [Ryder] allowed the office of attorney to be used in violation of law. The scheme which he devised was a deceptive, legalistic subterfuge-rightfully denounced by the canon as chicane."

21 ABA Canons No. 37 (in full):

It is the duty of a lawyer to preserve his client's confidences. This duty outlasts the lawyer's employment, and extends as well to his employees; and neither of them should accept employment which involves or may involve the disclosure or use of these confidences, either for the private advantage of the lawyer or his employees or to the disadvantage of the client, without his knowledge and consent, and even though there are other available sources of such information. A lawyer should not continue employment when he discovers that this obligation prevents the performance of his full duty to his former or to his new client.

If a lawyer is accused by his client, he is not precluded from disclosing the truth in respect to the accusation. The announced intention of a client to commit a crime is not included within the confidences which he is bound to respect. He may properly make such disclosures as may be necessary to prevent the act or protect those against whom it is threatened.

22 ABA Canons No. 5: "The primary duty of a lawyer engaged in public prosecution is not to convict, but to see that justice is done. The suppression of facts or the secreting of witnesses capable of establishing the innocence of the accused is highly reprehensible." The argument is by analogy but is weak because the prosecutor's role differs from that of the usual advocate:

The responsibility of a public prosecutor differs from that of the usual advocate; his duty is to seek justice, not merely to convict. This special duty exists because: (1) the prosecutor represents the sovereign and therefore should use restraint in the discretionary exercise of governmental powers, such as in the selection of cases to prosecute; (2) during trial the prosecutor is not only an advocate but he also may make decisions normally made by an individual client, and those affecting the public interest should be fair to all; and (3) in our system of criminal justice the accused is to be given the benefit of all reasonable doubts. With respect to evidence and witnesses, the prosecutor has responsibilities different from those of a lawyer in private practice: the prosecutor should make timely disclosure to the defense of available evidence, known to him, that tends to negate the guilt of the accused, mitigate the degree of the offense, or reduce the punishment. Further, a prosecutor should not intentionally avoid pursuit of evidence merely because he believes it will damage the prosecutor's case or aid the accused.

ABA Code of Professional Responsibility Canon 7, § EG 7-13 (effective Jan. 1, 1970).

23 ABA Canons No. 22: "The conduct of the lawyer before the Court and with other lawyers should be characterized by candor and fairness." A lawyer must divulge decisions 
requiring exposure of perjury, ${ }^{24}$ Canon 32 saying that no client should be given service or advice involving disloyalty to the law, ${ }^{25}$ and Canon 41 forbidding fraud or deception. ${ }^{26}$

In interpreting the Canons, the Bar Association's Committee on Professional Ethics has written that "we do not consider that either the duty of candor and fairness to the court as stated in Canon 22 or the provisions of Canons 29 and $41 \ldots$ are sufficient to override the purposes, policy and express obligations under Canon 37."27 The Committee therefore decided that an attorney who obtained a divorce for a client should not reveal the truth to the court when the client informs him that he committed perjury in securing the divorce, but rather should advise the client to inform the court and cease representation if the client fails to do so. ${ }^{28}$ The courts may not be so lenient:

We cannot permit a member of the bar to exonerate himself from a failure to disclose known perjury by a self-serving statement that in his judgment he had a duty of non-disclosure so as to protect his client which is paramount to his duty to disclose the same to the court, of which he is an officer, and to which he in fact, owes a primary duty. . . .29

The Bar Committee also said that if an attorney learned of a client's previous criminal record through confidential communication, he need not inform the court even though the client is given a lesser sentence

contrary to his client's case if his adversary fails to do so. ABA Comm. ON Professional Ethics, OpInions, No. 280 (1949), No. 146 (1935) [hereinafter cited as ABA OpINIONs].

24 ABA CANons No. 29: "The counsel upon the trial of a cause in which perjury has been committed owe it to the profession and to the public to bring the matter to the knowledge of the prosecuting authorities." See generally Freedman, Professional Responsibility of the Criminal Defense Lawyer: The Three Hardest Questions, in Symposium on Professional Ethics, 64 Mrch. L. REv. 1469 (1966).

25 ABA Ganons No. 32:

No client, corporate or individual, however powerful, nor any cause, civil or political, however important, is entitled to receive nor should any lawyer render any service or advice involving disloyalty to the law whose ministers we are, or disrespect of the judicial office, which we are bound to uphold, or corruption of any person or persons exercising a public office or private trust, or deception or betrayal of the public. When rendering any such improper service or advice, the lawyer invites and merits stern and just condemnation.

26 ABA Ganons No. 41 (in full):

When a lawyer discovers that some fraud or deception has been practiced, which has unjustly imposed upon the court or a party, he should endeavor to rectify it; at first by advising his client, and if his client refuses to forego the advantage thus unjustly gained, he should promptly inform the injured person or his counsel, so that they may take appropriate steps.

27 ABA Opinions No. 280 (1949). But cf., e.g., Clark v. State, 159 Tex. Crim. 187, 261 S.W.2d 339, cert. denied, 346 U.S. 855, rehearing denied, 346 U.S. 905 (1953).

28 ABA Opinions No. 287 (1953). Contra, In re King, 7 Utah 2d 258, 322 P.2d 1095 (1958).

29 In re King, 7 Utah 2d 258, 262, 322 P.2d 1095, 1097 (1958). 
because the court did not know of the prior conviction..$^{30}$ The committee nevertheless noted that the lawyer's duty to the court involved more than merely respect for the judicial office and candor and frankness to the judge:

It involves also the steadfast maintenance of the principles which the courts themselves have evolved for the effective administration of justice, one of the most firmly established of which is the preservation undisclosed of the confidences communicated to the lawyer in his professional capacity. ${ }^{31}$

The Committee appears to be saying that if the information is privileged as a matter of law ${ }^{32}$-not ethics-then disclosure would be unethical.

It is obvious that if the law requires disclosure, it is not unethical to disclose, and the Canons recognize this. For example, Canon 5 provides: "the lawyer is bound, by all fair and honorable means, to present every defense that the law of the land permits ...."33 Likewise, Canon 15 requires devotion and zeal "to the end that nothing be taken or be withheld from [the client] save by the rules of law, legally applied."34 It is also generally recognized that a lawyer may not hold in confidence a client's intent to commit a crime, fraudulent act or tort; only the client's communications with respect to previous crimes are protected. ${ }^{35}$

30 ABA OpINIONs No. 287 (1953).

31 Id.

32 "The canon, however, does not purport to state the law governing the attorneyclient privilege." NLRB v. Harvey, 349 F.2d 900, 906 (4th Cir. 1965). Whether communications between an insured and the insurer's attorney regarding a case of potential liability are privileged is a question of law and not a question of ethics. ABA OpINrons No. 247 (1942); H. DRINKER, Legal Ethics 132 (1953). In an informal opinion the ABA unit did say, "An attorney should refuse to disclose a privileged communication though the court send him to jail," but this does not make clear whether he should do so pending appeal or forever forbear from disclosure. Informal Opinion 317, reported in ABA OPINIONS (1957 ed.).

33 abA Canons No. 5 (emphasis supplied).

It is the right of the lawyer to undertake the defense of a person accused of crime, regardless of his personal opinion as to the guilt of the accused; otherwise innocent persons, victims only of suspicious circumstances, might be denied proper defense. Having undertaken such defense, the lawyer is bound, by all fair and honorable means, to present every defense that the law of the land permits, to the end that no person may be deprived of life or liberty, but by due process of law. Id.

34 ABA Canons No. 15 (emphasis supplied). The Canon is set forth in note 20 supra.

35 Alexander v. United States, 138 U.S. 353 (1891), citing Regina v. Cox, 14 Q.B.D. 162 (Cr. Cas. Res. 1884); In re Ryder, 263 F. Supp. 360, 364 (E.D. Va.), aff'd, 381 F.2d 713 (4th Cir. 1967) (per curiam); Clark v. State, 159 Tex. Crim. 187, 199, 261 S.W.2d 339, 347, cert. denied, 346 U.S. 855, rehearing denied, 346 U.S. 905 (1953); 8 WIGMORE § 2298; E. Morgan, Basic Problems of Evidence 104 (1954); Model Code of Evidence rule 212 (1942); UNIFORM RULES OF EVIDENCE 26(2); ABA CANONS No. 37, supra note 21; ABA Code of Professionar Responsiblutry Canon 4, § DR 4-101(C)(3). 
The newly promulgated Code of Professional Responsibility, which replaced the Canons effective January, 1970, makes it indisputably clear that the issue is really one of law, not of ethics. While noting that the attorney-client privilege is more limited than the ethical obligation to maintain confidences, ${ }^{36}$ the Code's Disciplinary Rules provide that a lawyer may reveal:

(2) Confidences or secrets when permitted under Disciplinary Rules or required by law or court order.

(3) The intention of his client to commit a crime and the information necessary to prevent the crime. ${ }^{37}$

More explicitly,

Because it interferes with the proper administration of justice, a lawyer should not suppress evidence that he or his client. has a legal obligation to reveal or produce. ${ }^{38}$

The Disciplinary Rules provide:

(A) In his representation of a client, a lawyer shall not: . .

(3) Conceal or knowingly fail to disclose that which he is required by law to reveal. ${ }^{39}$

It thus seems clear that the real issue is a legal question of the scope of the evidentiary attorney-client privilege. Any attempt to frame it in terms of the ethical considerations falls prey to the fallacy of petitio principii.

\section{Legaltity of Conduct Approach}

One approach, that apparently taken by the court in In re $R y d e r,{ }^{40}$ analyzes the attorney's conduct to determine whether he is violating a criminal law (such as a law prohibiting aiding and abetting), but then punishes him, not for violating the law, but for unethical conduct. This approach also seems to involve the logical fallacy of begging the question. A determination that the conduct is outside "proper" conduct for an attorney or outside the attorney-client privilege is a prerequisite for the conduct to be criminal, because, if within the privilege, the conduct is ipso facto legal. In Ryder, the client had consulted his attorney after committing a robbery. The client had secreted the

36 aba Code of Professionar. Responsibility Canon 4, \& EC 4-4. Confidences, of course, should be maintained even apart from official proceedings.

87 Id. at § DR 4-101(C).

$38 \mathrm{Id}$. at Canon 7, § EC 7-27.

$30 \mathrm{Id}$. at § DR 7-102.

10263 F. Supp. 360 (E.D. Va.), aff'd, 381 F.2d 713 (4th Cir. 1967) (per curiam). 
fruits of the crime-stolen money, together with a sawed-off shotgun-in a safety deposit box. Ryder, the attorney, armed with a power of attorney properly executed by his client, but on his own initiative, removed the money and sawed-off shotgun and placed them in a safety deposit box in his own name, allegedly intending to return the stolen money. When the F.B.I. discovered the boxes and their contents, charges of unprofessional conduct were brought against Ryder, and he was suspended from practice before the federal district court. The court ruled, ${ }^{41}$ and the ruling was sustained on appeal, ${ }^{42}$ that such conduct was beyond the bounds of legitimate professional conduct-a violation of Canon $32^{43}$-and that receiving stolen money and a sawed-off shotgun were crimes in themselves.4 The Ryder court only censured those acts as unprofessional conduct; it passed over the question whether the acts should be criminally punished. The opinion stresses the fact that the weapon was a sawed-off shotgun, possession of which is prohibited by federal law. ${ }^{45}$ It is by no means clear that, had the weapon itself been "legal," the court would still have taken disciplinary action against Ryder for secreting evidence. The court also stressed the fact that Ryder took possession of his own initiative:

It was Ryder, not his client, who took the initiative in transferring the incriminating possession of the stolen money and the shotgun from [the client]. Ryder's conduct went far beyond the receipt and retention of a confidential communication from his client. ${ }^{46}$

Thus, there is a possibility that the court might have treated the case differently had the client brought the money and the weapon to the attorney's office.

The Ryder opinion seems to contain a superficial analysis based on indignation rather than a reasoned examination of the problem. One could argue in favor of permitting the lawyer to retain physical evidence given to him by a client but oppose such withholding if the lawyer takes the initiative in obtaining the evidence. ${ }^{47}$ However, if the at-

$41 I d$. at 365,369 .

42381 F.2d at 713, 714.

43 Note 25 supra.

44263 F. Supp. at 369.

45 Id.; 28 U.S.C. § 5851 (1964).

46263 F. Supp. at 365.

47 The Ryder case presents an example of a situation where the attorney was "searched," since the F.B.I. had obtained the evidence from the second safety deposit box. The preferable approach would have been for the authorities to have ordered Ryder to produce the evidence after they had information concerning the transfer from the defendant's box to the attorney's. 
torney-client privilege is meant to give the client an assurance that he can confide in his attorney without fear, ${ }^{48}$ and if the withholding of physical evidence is to be justified on the grounds that such evidence is as essential for the proper preparation of the client's defense $e^{49}$ as are oral communications, then it would be incongruous to permit the attorney to elicit oral information from his client but to prohibit him from soliciting information in the form of physical evidence. If an attorney obtained physical evidence in the ordinary course of his investigation, it would not, of course, be protected by the privilege, just as oral evidence that is gained from third persons in the course of an investigation is ordinarily not so protected. ${ }^{50}$ However, where the physical evidence is received as a direct result of confidential communications, ${ }^{51}$ there is no logical reason why it should matter whether it was proffered as a result of the client's or the attorney's initiative.

The Ryder court's emphasis on the attorney's violation of substantive law is not particularly enlightening. The Model Penal Code considers one guilty of misdemeanor if he "conceals or removes any record, document or thing with purpose to impair its verity or availability in [an official] proceeding or investigation." 52 Thus, since the attorney's retention of any physical evidence or of a document would be unlawful, he could never withhold. However, it is a well-settled principle that an attorney may withhold his client's documents, ${ }^{53}$ such as confidential written communications from the client to the attorney, and it is generally recognized that the attorney may withhold any pre-existing document $t^{54}$ that the client could have refused to produce. ${ }^{55}$ Just as the attorney's act in advising generally is not considered "aiding and abetting," "56 so too his possession of a document under the stated cir-

48 Text at note 76 infra.

49 State ex rel. Sowers v. Olwell, 64 Wash. 2d 828, 833-34, 394 P.2d 681, 684 (1964).

508 Wigmore § 2317. See State ex rel. Sowers v. Olwell, 64 Wash. 2d 828, 831, 394 P.2d 681, 683 (1964).

51 See State ex rel. Sowers v. Olwell, 64 Wash. 2d 828, 831, 394 P.2d 681, 683 (1964).

52 Model Penal Code $\$ 241.7$ (Proposed Official Draft 1962).

538 WIGMORE $\S 2307(2)$, at 594. Temporary possesion only for preparation of defense would not, of course, be an illegal "purpose" under the Model Penal Code.

64 Generally a document existing before the formation of an attorney-client relationship.

55 See generally 8 Wigmore $\$ 2307$; C. MCCoRMick, HANDBooK of THE LAW OF EVIdeNCE § 93 (1954) [hereinafter cited as McCoRMick]; Meltzer, Required Records, The McCarran Act, and the Privilege Against Self-Incrimination, 18 U. Chr. L. Rev. 687 (1951); Note, The Attorney and His Client's Privileges, 74 YALE L.J. 539 (1965).

58 If the attorney is consulted after the commission of a crime and not during a continuing crime, his advice to his client is protected by the privilege. See generally authorities cited note 35 supra. If the court deems the advice "unprofessional" then it may well consider it unlawful. See the discussion of the Clark case in text at notes 63-67 infra. 
cumstances is not considered a violation of the law. ${ }^{57}$ Likewise his possession of a chattel should not be considered illegal.

Wigmore suggests that the pre-existing document rule arises from the client's privilege against self-incrimination and from the agency status held by his attorney rather than directly from the attorney-client privilege..$^{58}$ Although the privilege is usually thought personal to the client, ${ }^{60}$ one court $t^{60}$ permitted the attorney to claim the client's self-incrimination privilege, with respect to documents given to the attorney which the client could not have been compelled to produce and which could not have been obtained through a valid search. The court apparently rejected the attorney-client privilege as grounds for its decision because some of the documents were canceled checks, documents which could not be deemed confidential when written, ${ }^{61}$ and therefore would not meet the intent of confidentiality requirement of the attorney-client privilege in general. ${ }^{62}$ With respect to the type of evidence being discussed herein, the self-incrimination privilege is not as conclusive as it is with respect to documents, because the evidence being considered here can be obtained by a valid search if kept by the client. ${ }^{.3}$

In the present situation, as in the documents situation, to argue that the attorney's action is in violation of substantive law, such as "possession" statutes or the Model Penal Code provision, is to beg the question. It must first be determined whether the conduct is privileged as a matter of law, and, if so, whether it is within well-recognized exceptions to the criminal statute. The logical fallacy of begging the question is exhibited in Clark v. State. ${ }^{64}$ A telephone operator was permitted to testify to a conversation between a client and an attorney wherein the attorney advised his client to get rid of a murder weapon. The court said that the attorney's advice was beyond the bounds of legitimate professional conduct and therefore was not protected by the attorney-client privilege. ${ }^{65}$

07 See authorities cited note 55 supra.

588 WIGMORE § 2307.

50 Id. $\$ 2270$.

o0 United States v. Judson, 322 F.2d 460 (9th Cir. 1963). The Olwell court rejected this argument. 64 Wash. $2 \mathrm{~d}$ at 834-36, 394 P.2d at 685-86. See also Note, supra note 55.

61 United States v. Judson, 322 F.2d 460, 463 (9th Cir. 1963). See Note, supra note 55.

62 See note 82 infra.

63 Even the document rule may not be as conclusive as it once was. See, e.g., Lipton, Search Warrant in Tax Fraud Investigations, 56 A.B.A.J. 941 (1970).

B4 159 Tex. Crim. 187, 261 S.W.2d 339, cert. denied, 346 U.S. 855, rehearing denied, 346 U.S. 905 (1953).

65 Clark v. State, 159 Tex. Crim. 187, 199-200, 261 S.W.2d 339, 347, cert. denied, 346 U.S. 855, rehearing denied, 346 U.S. 905 (1953). 
In discussing the illegality of the attorney's conduct, the court wrote:

One who knowing that an offense has been committed conceals the offender or aids him to evade arrest or trial becomes an accessory. The fact that the aider may be a member of the bar and the attorney for the offender will not prevent his becoming an accessory.

Art. 77, P.C. defining an accessory contains the exception "One who aids an offender in making or preparing his defense at law" is not an accessory.

The conversation as testified to by the telephone operator is not within the exception found in Art. 77, P.C. When the Dallas voice [the attorney] advised the client to "get rid of the weapon" (which advice the evidence shows was followed) such aid cannot be said to constitute aid "in making and preparing his defense at law." It was aid to the perpetrator of the crime "in order that he may evade an arrest and trial."'66

First, the statute specifically excepted the attorney even if he did "aid to evade arrest and trial." Certainly destruction of the murder weapon is an aid to the client's defense at law, or perhaps the court deems the seriousness of the offense as affecting the scope of the legally permitted "aid." If advising the client to destroy the weapon is not within the attorney exception, then what "aid to evade arrest or trial" is to be considered within the exception for preparing a defense at law? Some such aid must be permitted or the attorney exception would be unnecessary. Thus, one must first determine the scope of the attorney-client privilege; then, ipso facto, anything outside that scope is unlawful, though it may well be punished only as unprofessional conduct, and not as a crime. Properly viewed, the Clark court's opinion really did nothing more than rule that the conversation was not protected by the attorney-client privilege because public policy dictated that such conduct should not be permitted in preparing a defense at law. Once having made that determination, the action was of course a violation of the statute. The point is, any conduct which the court deems to be properly undertaken by the attorney would be within the exception, even if it involves aiding in evading arrest or trial. The court determined the propriety of the conduct on public policy grounds apart from the statute and only then did it apply the statute to reinforce its argument.

In $R y d e r$, had the court concluded that possession of the money and gun were within the attorney-client privilege, it could have ruled that the statute did not apply, just as the Model Penal Code provision obvi- 
ously does not apply, as illustrated above, to documents. True, the analogy to documents ${ }^{87}$ may not be as appropriate with reference to the stolen money as to the shotgun. It is sometimes said, with respect to documents, that if someone other than the client had a superior right to possession of the document ${ }^{68}$ or chattel, ${ }^{69}$ then the client cannot refuse to produce it even if the production is incriminating. If the client could be compelled to produce, then the attorney could not refuse under the analysis of the documents rule. ${ }^{70}$ It could be argued that a client could not "give" his attorney stolen property because he had no title and hence no right to pass title. ${ }^{71}$ But, if it is admitted, and it would be difficult to argue otherwise, that an attorney would have to surrender the stolen property to its rightful owner after his client's trial, then the title point seems inconclusive. He could simply be constructive trustee for the owner. If the property is going to serve as evidence, the owner is not likely to regain possession until after the trial anyway. ${ }^{72}$

Thus, the legality of conduct approach, just like the ethical approach, is question begging. The solution must come from policy considerations, and for these, the background of the attorney-client privilege should be examined.

\section{Rationale of the Attorney-Glient Privilege}

The common law attorney-client privilege can be traced to the reign of Elizabeth $I$, when it was utilized in order to protect the oath and honor of the attorney-to protect his pledge of secrecy at a time when

67 Text at notes 52-62 supra.

68 MOdEL CODE of Evidence rule 206 (1942).

$60 \mathrm{Id}$.

708 WIGMORE \& 2307.

71 The Model Code of Evidence rule 206 uses an analysis similar to the "title" analysis in requiring production of incriminating documents or chattels by the possessor if someone else has a superior right to possession.

72 The document rule might be distinguished. Documents which belong to someone else often take on their incriminating character apart from the client's use of them while in his possession. The physical evidence being discussed herein has no significance at all apart from the client's connection with and use of it. If a client murders someone with another's gun, is there any doubt that he could not be compelled to produce the weapon, even though it is a chattel belonging to another and apparently within the Model Code of Evidence rule 206? Here the item took on its incriminating character in the possession of the client because of his use of it. A client may possess a document belonging to someone else and its contents may be incriminating, but the client's possession of it does not make it any more incriminating. A document is incriminating regardless of what the client does with it; the physical evidence takes on its incriminating character solely by virtue of its connection with the client and his use of it. The client's possession of a document owned by another is not likely to be the primary incriminating factor-the content is likely to be so. 
the breach of such pledge by an attorney or anyone else was regarded with public disfavor. ${ }^{73}$ "That doctrine, however, finally lost ground, and by the last quarter of the $1700 \mathrm{~s}$... . was entirely repudiated. The judicial search for truth could not endure to be obstructed by a voluntary pledge of secrecy, nor was there any moral delinquency or public odium in breaking one's pledge under force of the law."74 But the privilege remained, though with a rationale focusing more on the client than on the attorney. ${ }^{75}$ It was said to free the client from apprehension in consulting his attorney. ${ }^{76}$ It has also been suggested that the purpose of the privilege is to preserve the dignity of the individual and the inviolate personality. ${ }^{77}$

Whatever words are used, the reasoning is apparent. Laws, government regulations, and court rules-the system of government by laware too complex for the layman; he needs an expert spokesman, someone familiar with the "system" who can use that system to see that his client receives justice. ${ }^{78}$ For an attorney adequately to fulfill his function, he must know all the facts of his client's case. The client will not confide in his attorney if he thinks the information will be revealed and used against him..$^{79}$ On the other hand, there is no doubt that the privilege keeps potentially important facts from the jury. Justice, it is usually assumed, will best be served if all the facts are revealed and a reasoned judgment is rendered based thereon. Professor Wigmore has written, in regard to the privilege: "Its benefits are all indirect and speculative; its obstruction is plain and concrete." 80 But, the privilege has been praised. Professor McCormick writes: "The proposition is that the detriment to justice from a power to shut off inquiry to perti-

738 WIGMORE \& 2290.

74 Id.

75 See Chirac v. Reinicker, 24 U.S. (11 Wheat.) 280, 294 (1826) (Story, J.).

76 State ex rel. Sowers v. Olwell, 64 Wash. 2d 828, 832, 394 P.2d 681, 684 (1964); 8 WIGMORE §§ 2290-91. See Hunt v. Blackburn, 128 U.S. 464, 470 (1888), decree made absolute, 131 U.S. 403 (1889); MODEL CODE OF EvidENGE rule 210, comment $a$ at 146 (1942); Morgan, Introduction in ALI, MODEL CODE OF EvmENCE 25 (1942).

77 Gardner, A Re-evaluation of the Attorney-Client Privilege (pts. 1-2), 8 Vזr. L. REv. 279, 308, 316, 511-19 (1963).

78 Hunt v. Blackburn, 128 U.S. 464, 470 (1888), decree made absolute, 131 U.S. 403 (1889); McCormick \& 91; Morgan, supra note 76, at 25:

The orthodox justification for the present privilege stresses first the function of the lawyer in the administration of justice. In a complex society such as ours, with local legislative bodies, state legislatures and the United States Congress grinding out statutes and regulations after various stages of deliberation or lack of deliberation, many ill-drawn, many with varying implications, there can be no question of the need for trained technicians to advise men how to order their conduct. And under rules of procedure developed by courts and legislatures, the impossibility of a layman's preparing and conducting a lawsuit needs no demonstration. 79 Morgan, supra note 76 , at 26.

808 WIGMORE § 2291. 
nent facts in court, will be outweighed by the benefits to justice (not to the client) from a franker disclosure in the lawyer's office." 81

Many of the commentators are less than totally enthusiastic about the privilege. ${ }^{82}$ McCormick says that it would be hard to argue, absent the ingrained existence of the privilege as it is, that justice would be any less served by permitting the judge, at his discretion, to admit previously privileged communication if he felt justice so required.83 Presumably, however, McCormick would not permit admission of evidence, otherwise protected, such as a confession made to an attorney, since such admission would surely conflict with the constitutional right to counsel and the constitutional privilege against self-incrimination. Professor Morgan is also critical of the privilege and suggests that it is included in the Model Code of Evidence only because it would be politically impossible to abolish it.84 "There are," he writes, "no data to furnish a reasoned support for the privilege in general." 85 However, even Morgan recognizes that "[i]n situations where the privilege against self-incrimination is involved, the retention of the privilege is justified." 86 He continues: "There the justification rests not on the attorney-client privilege but upon a combination of the privilege against self-incrimination and the right of every person accused of crime to competent counsel."87 A New Jersey court agrees: "The attorney-client privilege is basic to a relation of trust and confidence that, though not given express constitutional security, is yet essentially interrelated with the specific constitutional guarantees of the individual's right to counsel and immunity from self-incrimination . . . ."88

Thus, whatever one may think of the privilege in such as civil cases where modern discovery rules might affect one's assessment, ${ }^{89}$ the privilege remains justifiable in criminal cases, where it may be necessary to effectuate the right to counsel and the privilege against self-incrimi-

81 McCormick § 91 (emphasis added).

82 E.g., Morgan, supra note 76, at 25-28; McCormick \& 91. See Radin, The Privilege of Confidential Communication Between Lawyer and Client, 16 CALIF. L. REv. 487, 491-92 (1928). The privilege, of course, is not unlimited. Its traditional statement is from Wigmore, 8 Wigmore § 2292: "(1) Where legal advice of any kind is sought (2) from a professional legal adviser in his capacity as such, (3) the communications relating to that purpose, (4) made in confidence (5) by the client, (5) are at his instance permanently protected (7) from disclosure by himself or by the legal adviser, (8) except the protection be waived."

83 McCoRMICK § 91 .

84 Morgan, supra note 76 , at 26-28.

$85 \mathrm{Id}$. at 27.

$86 \mathrm{Id}$.

87 Id.

88 State v. Kociolek, 23 N.J. 400, 415, 129 A.2d 417, 425 (1957).

80 E.g., FED. R. Civ. P. 26-37. 
nation. It is from this perspective-the conflicting duties and intereststhat the policy judgment must be made.

\section{The Policy Issue}

The policy issue may be stated simply: Do the benefits to justice of complete divulgence of facts and objects related to a crime by a client to his attorney, considering also the tangential support provided by the client's right to counsel and privilege from self-incrimination, ${ }^{90}$ outweigh the benefits to justice of full disclosure of evidence? In upholding the protection of the privilege as to an alleged murder weapon, the Supreme Court in State ex rel. Sowers $v$. Olwell" noted that "[g]enerally speaking, the public interest at times must yield to protect the individual." 22 In that case, a man accused of murder consulted an attorney who came into possession of a knife alleged to have been the murder weapon. The court was not clear on exactly how he got possession, whether directly from the client or as a direct result of the information supplied from the client. A subpoena duces tecum ordered the attorney to produce the weapon at a coroner's inquest. The attorney refused to comply and was cited for contempt. The state supreme court reversed on the grounds that the subpoena duces tecum was "defective on its face" because it required an attorney to violate the attorney-client privilege. ${ }^{.3}$ The court decided that the attorney could keep the weapon for a reasonable time to aid him in preparing his client's defense ${ }^{94}$ and that he then should turn the weapon over to the authorities on his own initiative. The court also noted that, with respect to the evidence thus obtained from defense counsel, the prosecution would be required to exercise extreme caution in introducing the evidence so that its source would not be revealed. ${ }^{95}$

The Olwell court may have been influenced by the fact that the attorney's client was convicted of murder ${ }^{90}$ and that the knife in the attorney's possession turned out not to have been the murder weapon. ${ }^{97}$ Still, the court made it clear that it did not think the balancing of interests would permit the attorney to withhold the evidence permanently, ${ }^{98}$ and it indicated that the defense attorney should keep the

90 On the theory that the more these be viewed as promoting justice the more likely one would perceive justice in the present attorney-client privilege context.

0164 Wash. 2d 828, 394 P.2d 681 (1964).

22 Id. at 832, 394 P.2d at 684.

93 Id.

94 Id. at $833-34,394 \mathrm{P} .2 \mathrm{~d}$ at $684-85$.

95 Id. at 834, 394 P.2d at 685.

96 Id. at $830 \mathrm{n} .1,394$ P.2d at 683.

97 Id.

88 Id. at 833, 394 P.2d at 684. 
weapon only as long as needed to aid in the preparation of his client's defense ${ }^{89}$ and should then surrender it voluntarily to the court. ${ }^{100}$ The court also indicated that after some such reasonable time compulsory process for production might be in order, ${ }^{101}$ even though the subpoena duces tecum in the case itself was deemed "defective on its face"102 because it required production of items protected by the attorneyclient privilege. The Olwell court apparently recognized the questionbegging nature of the ethical and criminality-of-conduct approaches for it commendably used a policy approach. The court felt that the purposes of the attorney-client privilege could best be served by requiring the prosecution, when introducing evidence obtained from counsel, to refrain from divulging the source of the evidence. ${ }^{103} \mathrm{By}$ thus avoiding any connection with the client or attorney in a testimonial sense, as would result if either produced the evidence in response to a subpoena duces tecum, the client's communication with his attorney is protected, but the state is given the same opportunity to get the evidence as it would have had by use of a search warrant if the items were still in the hands of the client. It is true that the prosecution may never find the item even if it searches for it. In that sense, the client's confidential disclosure is used to his detriment. ${ }^{104}$ However, anytime there is a balancing of interests and a compromise solution, it must be expected that neither interest will be protected to the utmost degree.

If evidence were obtained by search warrant from the client's home, connecting the evidence with the client would be a good deal easier for the prosecution than would be the case if it got the evidence from defense counsel with the stipulation that it must be introduced without reference to its source. This disadvantage could be said to be the prosecution's concession in order to protect the client's interests while not denying society the opportunity of having its courts consider all relevant evidence in arriving at a verdict. But one should not overlook the problems the prosecution might have in attempting to introduce evidence without reference to its source. Even if it could be connected to defendant by fingerprints or otherwise, serious questions might arise in the jury's mind if the origin of a piece of critical evi-

99 Id. at $833-34,394$ P.2d at 684.

$100 \mathrm{Id}$. at $834,394 \mathrm{P} .2 \mathrm{~d}$ at 685 .

$101 \mathrm{Id}$.

$102 \mathrm{Id}$. at $833,394 \mathrm{P} .2 \mathrm{~d}$ at 684 .

103 Id. at 834,394 P.2d at 685.

104 See generally Freedman, supra note 24, and critical replies following his article: Noonan, The Purposes of Advocacy and the Limits of Confidentiality, $64 \mathrm{MicH}$. L. REv. at 1485; Bress, Professional Ethics in Criminal Trials: 1 View of Defense Counsel's Responsibility, id. at 1493. 
dence were not disclosed. In addition to this burden on the prosecution, the Olwell court also permitted the attorney to keep the evidence for some length of time in order to aid him in preparing his client's defense. ${ }^{105}$ But such a privilege only raises additional questions: How long? A reasonable time? What is reasonable? Given the requirement placed on the prosecution in introducing this evidence, the only justification for permitting the attorney to keep the evidence at all is that it might aid him in the preparation of his client's defense. That purpose could be adequately served by requiring that the evidence be promptly turned over to the authorities, while providing that the attorney be entitled to repossession for such time as is required to aid him in preparing his case.

In many cases "aid in preparation" may be nothing more than a verbalism. Aside from aiding the client by destroying or refusing to produce the evidence, the attorney's defense of his client may not be greatly aided by possessing the evidence in the first place. If there is no real substance to the "aid in preparation" concept, then the Olwell solution holds essentially that the attorney must surrender the physical evidence but that the prosecution will have to avoid introducing it in any way which might clothe it with "testimonial" representations of the defendant through his attorney. That requirement effectively protects the client's self-incrimination privilege. It does not, however, resolve the right-to-counsel problem insofar as the client would be deterred from full disclosure and hence possibly be deemed to have been denied effective assistance of counsel. This consideration is of less importance if the observation made above-that such evidence really is not of much help in the preparation of the defense-is correct.

In the final analysis, however, one must turn to first principles. The purpose of the attorney-client privilege and the constitutional right to counsel and privilege against self-incrimination is to protect the innocent and not the guilty. If one could be sure an innocent man would never be convicted, then all constitutional rights of criminals -except those of a purely humane nature ${ }^{106}$ - could be abandoned. But

105 Courts are not likely to allow the time of disclosure to be decided by counsel. The attorney will not be permitted to "bide his time and decide himself when the disclosure should be made." In re King, 7 Utah 2d 258, 262, 322 P.2d 1095, 1098 (1958).

108 Historical analysis supports the view that the self-incrimination privilege itself was founded on humane considerations-that it is unreasonable to subject a human being to the dilemma of committing perjury or giving up his self-preservation. See, e.g., discussion in Meltzer, supra note 55. This consideration seems more relevant to self-incrimination in the sense of being forced to testify involuntarily than to the collateral self-incrimination considerations involved herein. The "protection of the innocent" purpose stated in the text is not meant to imply that this is the only purpose or justification for the rights 
since one cannot be sure, the rights of the accused must be maintained. Still, however, in considering what scope should be given to existing privileges it is indeed appropriate to consider the risk that a narrow scope will expose the innocent to punishment. There is little chance that the refusal to expand the attorney-client privilege to protect the fruits or instrumentalities of a crime given to an attorney by his client would operate to create a serious risk for the innocent. Discrepancies in ability of counsel would have far greater impact, yet the right to counsel is not deemed denied as long as the counsel is reasonably competent.

and privileges. But in this author's opinion, the "risk to the innocent" approach seems to be a legitimate contemporary criterion and has special merit in deciding issues of scope such as the one discussed herein. 